\title{
Light- and Electron-Microscopic Localization of Basic Fibroblast Growth Factor in Adult Rat Retina
}

\author{
By \\ Akihiro MORIMOTO' ${ }^{1}$, Seiji MATSUDA ${ }^{1}$, Kunihiro URYU ${ }^{1}$, Hiroko FUJITA ${ }^{1}$, Nobuaki \\ OKUMURA $^{2}$ and Masahiro SAKANAKA ${ }^{1 *}$ \\ ${ }^{1}$ Department of Anatomy, Ehime University School of Medicine. Shigenobu. Onsen-gun, Ehime 791-02, Japan \\ ${ }^{2}$ Division of Protein Metabolism, Institute for Protein Research. Osaka University, Suita, Osaka 565, Japan \\ - Received for Publication, January 13, $1993-$

\begin{abstract}
Key Words: basic fibroblast growth factor, rat, retina, immunoblot, immunohistochemistry, electron microscopy
Summary: An antiserum against basic fibroblast growth factor (bFGF) was characterized by immunoblot and used to localize bFGF-immunoreactivity in the adult rat retina. Crude homogenate of the retina, when examined with immunoblotting, exhibited a main band with the same molecular weight (18kDa) as bFGF. Light microscopic immunohistochemistry demonstrated intense bFGF staining in the photoreceptor outer segments and the outer plexiform layer, and weak immunostaining in some cells of the outer nuclear layer, inner nuclear layer and ganglion cell layer. The most intense bFGFimmunoreactivity was noted in glial (Müller) cells with vertically oriented thin processes. There were also immunoreactive pigment epithelial cells and mesenchymal cells in the choroid. Under electron microscopy, the outer plexiform layer was found to contain immunoreactive products exclusively in the axon terminals of photoreceptor cells which formed synapses with bipolar cell processes. The more widespread and uneven localization of bFGF-immunoreactivity in the mature rat retina than previously demonstrated suggests that endogenous bFGF is involved in complex physiological events other than retinal regeneration and histogenesis.
\end{abstract}

Basic fibroblast growth factor (bFGF), isolated from the brain and pituitary (Bohlen et al., 1984; Gospodarowicz et al., 1984; Esch et al., 1985; Pettmann et al. 1985), has been shown to stimulate the proliferation and differentiation of mesodermally derived cells as well as to facilitate the survival and neurite extension of neurons cultured from different brain regions (Gospodarowicz et al., 1983; Gospodarowicz et al., 1986; Morrison et al., 1986; Walicke et al., 1986; Gensburger et al., 1987; Walicke et al., 1988). Immunohistochemical studies have demonstrated it in neurons and astrocytes of the brain (Pettmann et al., 1986; Janet et al., 1987; Grothe et al., 1991; Gomez-Pinilla et al., 1992; Matsuda et al., 1992; Weise et al., 1992) and in certain peripheral tissues (DiMario et al., 1989; Grothe et al., 1989; Joseph-Silverstein et al., 1989; Kardami et al., 1989; Okada et al., 1992). bFGF also mediates the differentiation and maintenance of photoreceptors (Faktorovich et al., 1990; Lavail et al., 1991) and induces retinal regeneration in the chick embryo (Park et al., 1989). Previous physiological studies have shown that bFGF has retinotrophic functions in all the species examined to date, but there are discrepancies in the recent immunohistochemical studies on retinal bFGF in cows, lampreys and goldfish (Hanneken et al., 1989; Rubunson et al., 1991; Raymond et al., 1992). In the bovine retina, only developing capillary endothelial cells are immunoreactive for bFGF (Hanneken et al., 1989), whereas bFGF is widely distributed in the retinas of the fish species (Rubuson et al., 1991; Raymond et al., 1992). More recently, Gao and Hollyfield (1992) have shown bFGF in Muller cells and pigment epithelial cells of the adult rat retina, using only light microscopic immunohistochemistry. However, the selective demonstration of bFGF in non-neuronal cells of the adult rat retina is not necessarily reconciled with previous studies which suggest that bFGF is detected in neurons of the mature rat brain (Pettmann et al., 1986; Janet et al., 1987; Grothe et al., 1991; Gomez-Pinilla et al., 1992: Matsuda et al., 1992; Weise et al., 1992). With immunoblot, and light- and electron-microscopic immunohistochemistry, the present study was designed to re-investigate the location of bFGF-like molecules in the mature rat retina.

* To Whom all correspondence should be addressed. 


\section{Materials and Methods}

Wistar male rats weighing approximately $200 \mathrm{~g}$ were housed at constant temperature $\left(22^{\circ} \mathrm{C}\right)$ with a 12:12 light-dark cycle and given food and water ad libitum. The following experiments were conducted in accordance with the Guide for Animal Experimentation at Ehime University School of Medicine.

\section{Immunoblot analysis}

Four animals were sacrificed by decapitation; the retinas were frozen in liquid nitrogen and kept (for no longer than two days) at $-80^{\circ} \mathrm{C}$ till use. They were homogenized in a solution consisting of $320 \mathrm{mM}$ sucrose, $2 \mathrm{mM}$ EDTA and $2 \mathrm{mM}$ PMSF. In a study of the reactivities of bFGF antiserum to acidic FGF (aFGF), bFGF and crude retinal extract, both factors (10 ng each) and $10 \mu \mathrm{g}$ of retinal homogenate were subjected to SDS-polyacrylamide gel electrophoresis and subsequent silver staining or immunoblot analysis as described elsewhere (Towbin et al., 1979; Okumura et al., 1989; Desaki et al., 1992; Okada et al., 1992).

\section{Immunohistochemistry}

Four animals were anesthetized with pentobarbital $(40 \mathrm{mg} / \mathrm{kg})$ and perfused transcardially, first with $50 \mathrm{ml}$ of ice-cold saline, then with $300 \mathrm{ml}$ of $4 \%$ paraformaldehyde- $0.075 \%$ glutaraldehyde- $0.2 \%$ picric acid in $0.1 \mathrm{M}$ phosphate buffer (PB) ( $\mathrm{pH} 7.4$ ) (Somogyi et al., 1982). Immediately after perfusion, the retina was dissected out and cut into $60 \mu \mathrm{m}$ sections with a microslicer. The sections were immunostained with bFGF antiserum as described previously (Desaki et al., 1992; Matsuda et al., 1992). Half of the sections were mounted on gelatin-coated slides for light microscopic observation. The others were postfixed with $1 \%$ osmium tetroxide, dehydrated in a graded series of ethanol while being stained with $1 \%$ uranyl acetate in $70 \%$ ethanol, transferred to propylene oxide and embedded in epoxy resin. Ultrathin sections were cut with a Reichert ultramicrotome and observed in an electron microscope. Control sections were incubated with the primary antiserum that had been adsorbed with an excess of bFGF, then processed as described above.

\section{Results}

\section{Immunoblot}

The bFGF antiserum used in this study recognized purified bFGF with a molecular weight of $18 \mathrm{kDa}$, but not aFGF (Fig. 1). Crude homogenate of the retina, when examined with immunoblotting,
(kDa)

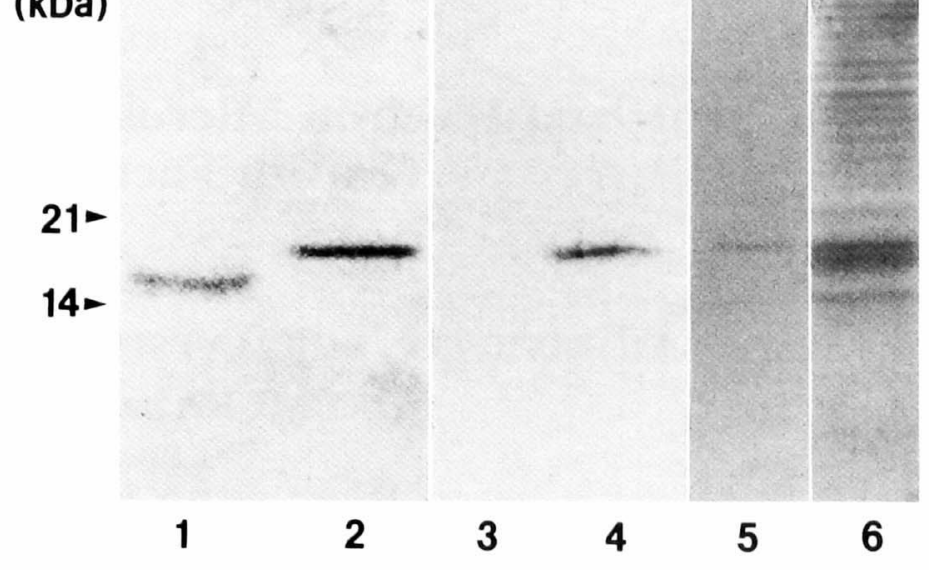

Fig. 1. aFGF (lanes 1,3) and bFGF (lanes 2, 4) were subjected to SDS-polyacrylamide gel electrophoresis and then silver staining (lanes 1,2) or immunoblot analysis (lanes 3, 4) with bFGF antiserum. Note that this antiserum recognizes bFGF but not aFGF (lanes 3,4). Crude homogenate of the rat retina, when examined with immunoblotting, also exhibits a main band with the same molecular weight (18 kDa) as bFGF (lane 5). Lane 6 shows silver staining of the retinal homogenate.

exhibited a main band of the same molecular weight (18 kDa) as bFGF (Fig. 1).

\section{Immunohistochemistry}

Under light microscopy, bFGF-immunoreactivity was noted in the inner part of photoreceptor cell outer segments, whereas photoreceptor cell bodies were only occasionally labeled with bFGF antiserum (Fig. 2). The outer plexiform layer close to the innermost part of the outer nuclear layer was also intensely immunoreactive for bFGF (Fig. 2). A small number of cells in the inner nuclear layer exhibited feeble immunostaining; cells in the innermost cell row appeared to be more frequently immunopositive than those in the outer cell rows (Fig. 2). A few ganglion neurons also contained immunoreaction materials in the cytoplasm. Besides the above retinal cells of neuronal origin, many glial (Müller) cells with vertically oriented thin processes, some mesenchymal cells in the choroid and pigment epithelial cells were endowed with bFGF immunoreactivity (Fig. 2). Pretreatment of bFGF antiserum with an excess of bFGF abolished all immunoreactions (Fig. 2d).

The immunoreactive outer plexiform layer in proximity to the inner nuclear layer, when examined with electron microscopy, was found to contain bFGFlike materials in the axon terminals of photorecepter cells which formed synapses with bipolar cell dendrites devoid of immunoreaction deposits (Fig. 3a). Part of the photoreceptor (possibly cone) outer 


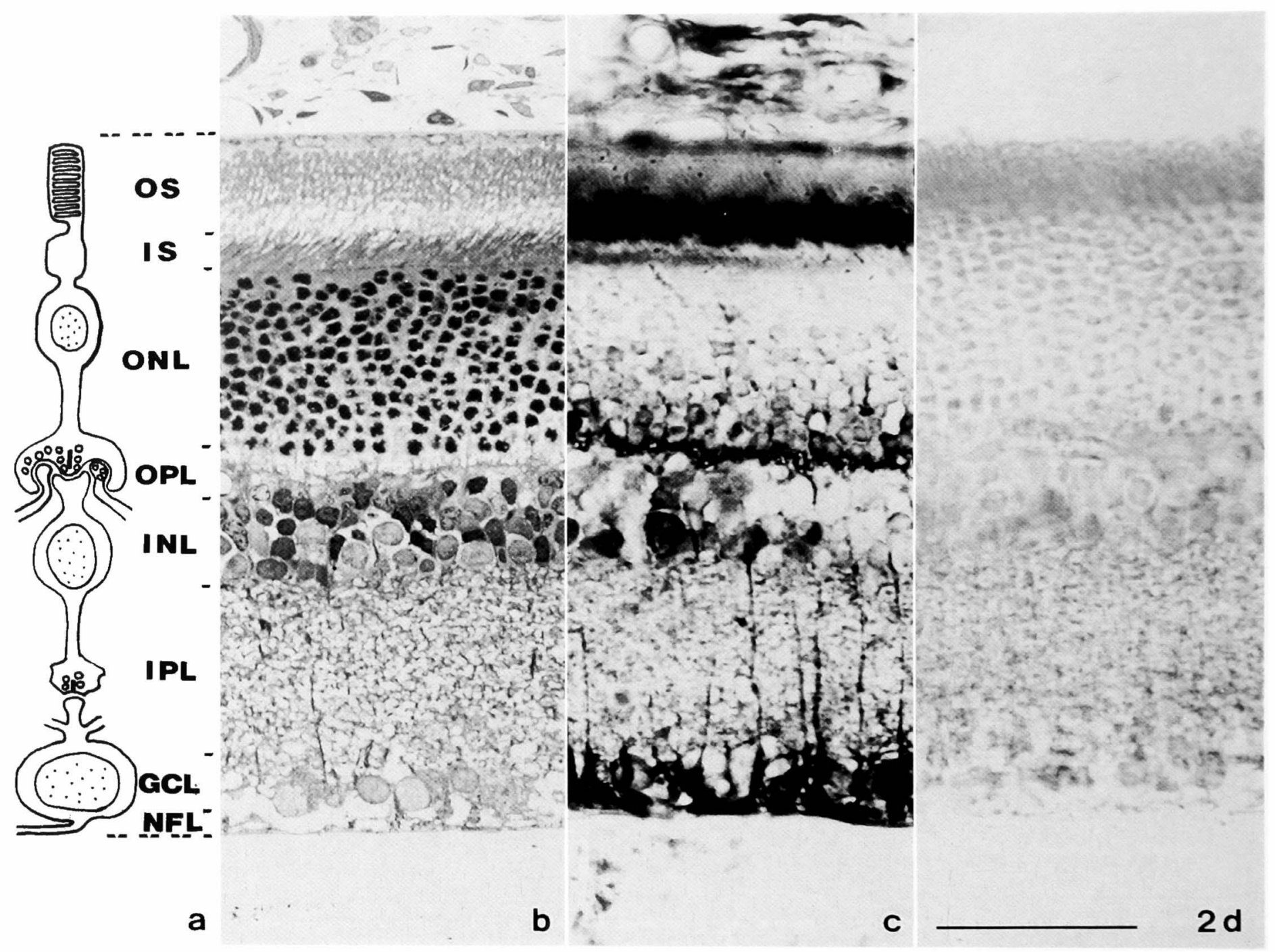

Fig. 2. a: Diagram of photoreoptor, bipolar and ganglion cells in the retina. OS, outer segment; IS, inner segment; ONL, outer nuclear layer; OPL, outer plexiform layer; IPL, inner plexiform layer; GCL, ganglion cell layer: NFL, nerve fiber layer.

b: Bright-field photomicrograph showing individual retinal layers in a semi-thin section stained with toluidine blue.

c: Bright-field photomicrograph showing bFGF immunoreactivity in the mature rat retina.

d: Bright-field photomicrograph showing disappearance of bFGF-immunoreactive structures in a negative control section of rat retina. bar $=50 \mu \mathrm{m}$.

segments with a lamellar structure was immunoreactive for bFGF (Fig. 3b). The above immunoreactions were not seen in control electron micrographs (Fig. 3c, d). Müller cells were most intensely labeled with bFGF antiserum as expected from the light microscopic observation, and they were seen in close apposition to retinal ganglion cells with or without bFGF-immunoreactivity (Fig. 3e). In the choroid, long tapering processes of putative mesenchymal cells were immunopositive, whereas vascular endothelial cells did not exhibit bFGF immunoreactivity (Fig. 3f).

\section{Discussion}

Using an antiserum against rat bFGF (amino acid 1-23), Gao and Hollyfield (1992) suggested that only Müller cells and pigment epithelial cells contain bFGF-like materials in the adult rat retina. They further showed that antisera against bovine/human bFGF recognize bFGF-like molecules exclusively in the ganglion cell layer, inner nuclear layer and pigment epithelium of the mature rat retina. Since serine residue is present at position 18 in bovine bFGF and absent from the position in rat bFGF, the first 25 amino acid residues of bovine and rat bFGFs, when used as antigens for antibody production, may have yielded antisera that are directed to different epitopes with or without the serine residue (Gao and 


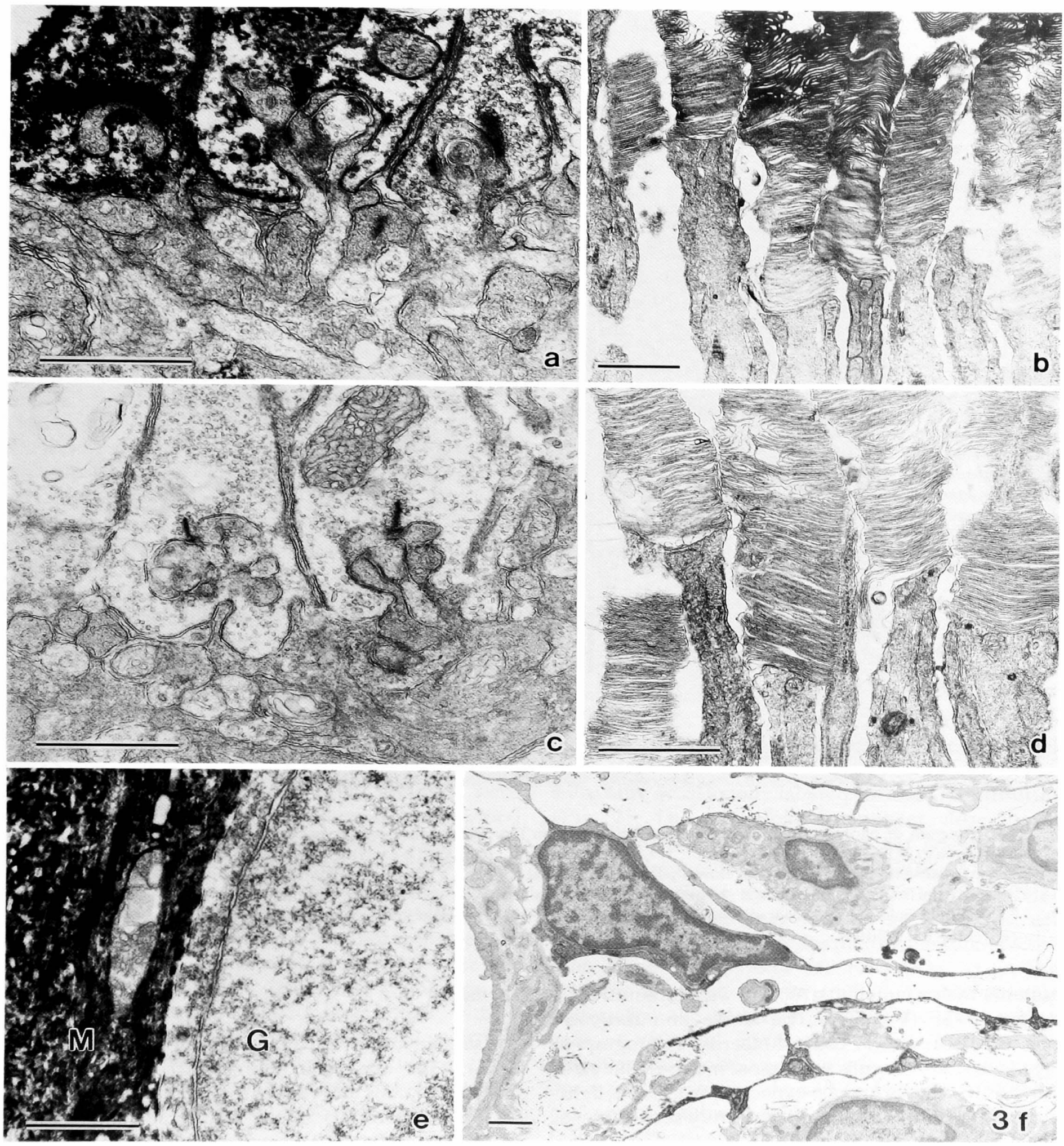

Fig. 3. a: Electron micrograph showing bFGF immunoreactivity in the axon terminals of two photoreceptor cclls, which form synapses with non-immunoreactive bipolar cell dendrites. bar $=1 \mu \mathrm{m}$.

b: Electron micrograph showing bFGF immunoreactivity in the outer segment of a photoreceptor cell. bar $=1 \mu \mathrm{m}$

c,d: Electron micrograph showing disappearance of bFGF immunoreactivity within photoreceptor nerve endings (c) and outer segments (d) in negative control sections, $c$, bar $=1 \mu \mathrm{m} ; \mathrm{d}$, bar $=1 \mu \mathrm{m}$.

e: Electron micrograph showing bFGF immunoreaction in a Müller cell $(\mathrm{M})$ apposed closely to a ganglion cell( $\mathrm{G})$. bar $=1 \mu \mathrm{m}$

f: Electron micrograph showing bFGF immunoreaction in mesenchymal cells of the choroid. bar $=1 \mu \mathrm{m}$. 
Hollyfield, 1992). To be more specific, Gao and Hollyfield speculated that the differential bFGF staining patterns were caused by the sequence difference between bovine and rat bFGFs. However, they did not take antibody sensitivity into consideration or provide any information on the sensitivity of their antibodies by immunoblot analysis, despite the fact that photoreceptor cells and inner nuclear layer cells are immunoreactive in the developing but not mature retina (Gao and Hollyfield, 1992). The antiserum against bovine bFGF used in the present study reacts well with bFGF-like malecules in $10 \mu \mathrm{g}$ of retinal crude homogenate, and thus appears to exhibit a higher sensitivity than the other antisera so far employed (Raymond et al., 1992). With the highly sensitive antiserum, the present study showed bFGF immunoreactivity not only in Müller cells and pigment epithelium but also in photoreceptor cells and cells of the inner nuclear layer within the adult rat retina, suggesting that $\mathrm{bFGF}$ in the photoreceptor and inner nuclear layers, even though decreasing in content with age, does exist within the mature rat retina. It is likely that our bFGF antiserum recognizes amino acid sequences common to bovine and rat bFGFs. In support of the speculation that our bovine bFGF antiserum crossreacts with rat bFGF, hair matrix cells of the rat vibrissae which are immunostained intensely with the bFGF antiserum have been shown to express rat bFGF mRNA (Okada et al., 1992).

Microslicer-sectioning immediately after perfusion-fixation may also have contributed to satisfactory demonstration of retinal bFGF-immunoreactivity in the present study. In our experience, postfixation of the retina subjected to perfusionfixation did not yield good immunostaining, possibly due to tissue overfixation which is assumed to preclude preservation of the antigenicity of retinal bFGF (Gao and Hollyfield, 1992). Because the retina is not endowed with blood vessels, transcardial perfusion appeared not to overfix the tissue and immediate sectioning with a microslicer may have made the exposure time of tissue to the fixative as short as possible in this study. Taken together, microslicersectioning takes less time for tissue processing than cryostat-sectioning which spends usually 24 hours to clear out the fixative completely from the tissue due to immersion in a cryoprotective reagent, and thus microslicer-sectioning may be adequate for bFGF immunohistochemistry.

The present study demonstrated intense bFGF staining in the axon terminals of photoreceptor cells in synaptic contact with bipolar cell dendrites within the outer plexiform layer. This is in contrast to a previous study which showed more intense immunostaining in the cell bodies and proximal processes of goldfish photoreceptor cells than in the nerve terminals (Raymond et al., 1992). The discrepancy in retinal bFGF staining between the rat and the goldfish may be attributed to the species difference. The localization of bFGF immunoreactivity in the axon endings of rat photoreceptor cells resembles that of bFGF receptor in goldfish and bovine retinas (Schweigerer et al., 1987; Hanneken et al., 1989). If rat bFGF receptor is present in the same retinal area, bFGF in the photoreceptor nerve endings may act as an autocrine regulator in situ, as suggested elsewhere (Schweigerer et al., 1987; Okumura et al., 1989; Logan et al., 1991).

Another feature of immunostaining in the rat retina is the presence of bFGF-like materials in the outer segments of photoreceptor cells, which underwent continuous outward elongation as the pigment epithelium phagocytized and destroyed the tip of photoreceptor outer segments. It is tempting to speculate that bFGF not only facilitates neutrite extension of a variety of central neurons (Morrison et al., 1986; Walicke et al., 1986) but also regulates the outward extension of photoreceptor outer segments. In accord with the present immunohistochemical results, a previous biochemical study isolated bFGF from bovine photoreceptor outer segments (Mascarelli et al., 1987).

In lower vertebrates exogenous bFGF has been shown to participate in the transdifferentiation of pigment epithelial cells into photoreceptor cells (Pittack et al., 1991) and in retinal regeneration in response to certain injuries (Park et al., 1989), and endogenous bFGF might act in the same way. The mature rat retina, even though it has less potency of transdifferentiation and/or regeneration, may be under the control of endogenous bFGF in normal and pathologic conditions.

\section{References}

1) Bohlen. P., Baird, A., Esch, F., Ling, N. and Gospodarowicz. D.: Isolation and partial molecular characterization of pituitary fibroblast growth factor. Proc. Natl. Acad. Sci. U.S.A., 81: 5364-5368, 1984.

2) Desaki, J., Matsuda, S., Okumura, N., Koyama, Y. and Sakanaka, M.: Fine structurc of nerve processes containing basic fibroblast growth factor in muscle spindles of the rat masseter muscle, Neurosci. Lett. 137: 237-240, 1992.

3) DiMario, J., Buffinger. N., Yamada, S. and Strohman. R. C.: Fibroblast growth factor in the extracellular matrix of dystrophic $(\mathrm{mdx})$ mouse muscle. Scicnce., 244: 688-690. 1989.

4) Esch, F., Baird, A.. Ling, N., Ueno, N., Hill. F., Denoroy, L., Klepper, R.. Gospodarowicz. D. Bohlen, P. and Guillemin. R.: Primary structure of bovine pituitar basic fibroblast growth factor (FGF) and comparison with the amino-terminal sequence of bovine acidic FGF, Proc. Natl Acad. Sci. U.S.A., 82: 6507-6511, 1985.

5) Faktorovich, E. G.. Stcinberg. R. H. Y Yasumura, D 
Matthes, M. T. and Lavail, M. M.: Photoreceptor degeneration in inherited retinal dystrophy delayed by basic fibroblast growth factor, Nature., 347: 83-86, 1990.

6) Gao, H. and J. G. Hollyfield: Basic fibroblast growth factor (bFGF) immunolocalization in the rodent outer retina demonstrated with an anti-rodent bFGF antibody. Brain Res. 585: 355-360, 1992.

7) Gensburger, C., Labourdette, G. and Sensenbrenner, M.: Brain basic fibroblast growth factor stimulates the proliferation of rat neuronal precursor cell in vitro, FEBS Letters., 217: 1-5, 1987.

8) Gomez-Pinilla, F., Lee J. W. and Cotman, C.W.: Basic FGF in adult rat brain: cellular distribution and response to entorhinal lesion and fimbria-fornix transection, J. Neurosci., 12: 345-355, 1992.

9) Gospodarowicz, D., Cheng, J. and Lirette, M.: Bovine brain and pituitary fibroblast growth factors, comparison of their abilities to support the proliferation of human and bovine vascular endothelial cells, J. Cell Biol., 97: 1677-1685, 1983.

10) Gospodarowicz, D., Cheng, J., Lui, G-M., Baird, A. and Bohlen, P.: Isolation of brain fibroblast growth factor by heparin-sepharose affinity, chromatography: identity with pituitary fibroblast growth factor, Proc. Natl. Acad. Sci. U.S.A., 81: 6963-6967, 1984.

11) Gospodarowicz, D., Neufeld, G. and Schweigerer, L.: Molecular and biological characterization of fibroblast growth factor, an angiogenic factor which also controls the proliferation and differentiation of mesoderm and neuroectoderm derived cells, Cell Differ., 19: 1-17, 1986.

12) Grothe, C. and Unsicker, K.: Immunocytochemical localization of basic fibroblast growth factor in bovine adrenal gland, ovary, and pituitary, J. Histochem, Cytochem., 37: 1877-1883, 1989.

13) Grothe, C., Zachmann, K. and Unsicker, K.: Basic FGFlike immunoreactivity in the developing and adult rat brainstem, J. Comp. Neurol., 305: 328-336, 1991.

14) Hanneken, A., Lutty, G.A., Mcleod, D. S., Robey, F., Harvey, A. K. and Hjelmeland, L. M.: Localization of basic fibroblast growth factor to the developing capillaries of the bovine retina, J. Cell. Physiol., 138: 115-120, 1989.

15) Janet, T., Miehe, M., Pettmann, B., Labourdette, G. and Sensenbrenner M.: Ultrastructural localization of fibroblast growth factor in neurons of rat brain, Neurosci. Lett., 80: $153-157,1987$.

16) Joseph-Silverstein, J., Consigli, S. A., Lyser, K. M. and Ver Pault, C.: Basic fibroblast growth factor in the chick embryo: immunolocalization to striated muscle cells and their precursors, J. Cell Biol., 108: 2459-2466, 1989.

17) Kardami, E. and Fandrich, R. R.: Basic fibroblast growth factor in atria and ventricles of the vertebrate heart, J. Cell Biol., 109: 1865-1875, 1989.

18) Lavail, M. M., Faktorovich, E. G., Hepler, J. M., Pearson, K. L., Yasumura, D., Matthes, M. T., Steinberg, R. H.: Basic fibroblast growth factor protects photoreceptors from light-induced degeneration in albino rats, Ann. N Y Acad. Sci., 638: 341-347, 1991.

19) Logan, A., Gonzalez, A. M., Buscaglia, M. L., Black, E. G., Sheppard, M. C.: Basic fibroblast growth factor is an autocrine factor for rat thyroid follicular cells, Ann. N Y Acad. Sci., 638: 453-455, 1991.

20) Mascarelli, F., Raulais, D. and Courtois, Y.: Fibroblast growth factor phosphorylation and receptors in rod outer segments, EMBO J. 8: 2265-2273, 1987.

21) Matsuda, S., Desaki, J., Okumura, N., Shiosaka, S., Imaoka, S. and Sakanaka, M.: Basic fibroblast growth factor-like immunoreactivity in the trigeminal proprioceptive and motor systems, Brain Research., 577: 92-100, 1992.

22) Morrison, R. S., Sharma, A., De Vellis, J. and Bradshaw, R. A.: Basic fibroblast growth factor supports the survival of cerebral cortical neurons in primary culture, Proc. Natl. Acad. Sci. U.S.A., 83: 7537-7541, 1986.

23) Okada, K., Matsuda, S., li, Y., Okumura, N., Uryu, K., Fujita, H. and Sakanaka, M.: Basic fibroblast growth factorlike immunoreactivity in the rat trigeminal sensory system and peri-oral skin with vibrissae. Cell Tissue Res., in press, 1992.

24) Okumura, N., Takimoto, K., Okada, M. and Nakagawa, H.: C6 glioma cells produce basic fibroblast growth factor that can stimulate their own proliferation, J. Biochem., 106: 904-909, 1989.

25) Park, C. M. and Hollenberg, M. J.: Basic fibroblast growth factor induces retinal regeneration in vivo, Dev. Biol., 134: 201-205, 1989

26) Pettmann, B., Weibel, M., Sensenbrenner, M. and Labourbdette, G.: Purification of two astroglial growth factors from bovine brain, FEBS Lett., 189: 102-108, 1985.

27) Pettman, B., Labourdette, G., Weibel, M. and Sensenbrenner, M.: The brain fibroblast growth factor (FGF) is localized in neurons, Neurosci Lett., 68: 175-180, 1986.

28) Pittack, C., Jones, M., Reh, T. A.: Basic fibroblast growth factor induces retinal pigment epithelium to generate neural retina in vitro, Development., 113: 577-88, 1991.

29) Raymond, P. A., Barthal, L. K. and Rounsifer, M. E.: Immunolocalization of basic fibroblast growth factor and its receptor in adult goldfish retina, Exp. Neurol., 115: 73-78, 1992.

30) Rubunson, K.: Distribution of basic fibroblast growth factor in developing lamprey retina, Invest. Ophthal. Vis. Sci. Suppl., 32: 1229, 1991.

31) Schweigerer, L., Neufeld, G., Friedman, J., Abraham, J.A., Fiddes, J. C. and Gospodarowicz, D.: Capillary endothelial cells express basic fibroblast growth factor, a mitogen that promotes their own growth, Nature., 7: 257-259, 1987.

32) Somogyi, P. and Takagi, H.: A note on the use of picric acid-paraformaldehyde fixative for correlated light and electron microscopic immunocytochemistry, Neuroscience, 7: 1779-1783, 1982.

33) Towbin, H., Staehelin, T. and Goudon, J.: Electrophoretic transfer of proteins from polyacrylamide gels to nitrocellulose sheet: Procedure and some applications, Proc. Natl. Acad. Sci. U.S.A., 76: 4350-4354, 1979.

34) Walicke, P., Cowan, M. W., Ueno, N., Baird, A. and Guillemin, R.: Fibroblast growth factor promotes survival of dissociated hippocampal neurons and enhances neurite extension, Proc. Natl. Acad. Sci. U.S.A., 83: 3012-3016, 1986.

35) Walicke, P. A.: Basic and acidic fibroblast growth factors have trophic effects on neurons from multiple CNS regions, J. Neurosci., 8: 2618-2627, 1988.

36) Weise, B., Unsicker, K. and Grothe, C.: Localization of basic fibroblast growth factor in a subpopulation of rat sensory neurons, Cell Tissue Res., 267: 125-130, 1992. 